\begin{tabular}{|l|l|l|}
\hline \multicolumn{2}{|c|}{ PublisherInfo } \\
\hline \hline PublisherName & $:$ & BioMed Central \\
\hline \hline PublisherLocation & $:$ & London \\
\hline \hline PublisherImprintName & $:$ & BioMed Central \\
\hline \hline
\end{tabular}

\title{
What makes fruit pear-shaped?
}

\begin{tabular}{|l|l|l||}
\hline \multicolumn{2}{|c|}{ ArticleInfo } \\
\hline \hline ArticleID & $:$ & 4590 \\
\hline \hline ArticleDOI & $:$ & $10.1186 /$ gb-spotlight-20020925-01 \\
\hline \hline ArticleCitationID & $:$ & spotlight-20020925-01 \\
\hline \hline ArticleSequenceNumber & $:$ & 256 \\
\hline \hline ArticleCategory & $:$ & Research news \\
\hline ArticleFirstPage & $:$ & 1 \\
\hline \hline ArticleLastPage & $:$ & 2 \\
\hline \hline & & RegistrationDate : 2002-9-25 \\
\hline ArticleHistory & $:$ & OnlineDate \\
\hline \hline ArticleCopyright & $:$ & BioMed Central Ltd2002-9-25 \\
\hline \hline ArticleGrants & $:$ & \\
\hline \hline ArticleContext & $:$ & 130593311 \\
\hline \hline
\end{tabular}




\section{Jonathan B Weitzman}

Email: jonathanweitzman@hotmail.com

Fruit-crop domestication has led to a flourishing of fruit shape variation, the molecular basis of which remains unexplained. In the Early Edition of the Proceedings of the National Academy of Sciences, Liu et al. describe characterization of the OVATE gene previously associated with a major quantitative trait locus (QTL) controlling pear-shaped fruit development in tomatoes. They cloned the OVATE gene and identified a premature stop codon associated with the ovate pear-shaped phenotype. Overexpression of OVATE affected plant growth, fruit shape and floral organ development. OVATE encodes a novel protein with a nuclear localization signal and a 70-residue carboxyl-terminal domain that is conserved in tomato, Arabidopsis and rice. The authors suggest that OVATE might represent a new class of genes that regulate plant growth and fruit shape.

\section{References}

1. Proceedings of the National Academy of Sciences, [http://www.pnas.org]

2. Exploitation of Arabidopsis-tomato synteny to construct a high-resolution map of the ovatecontaining region in tomato chromosome 2

3. A new class of regulatory genes underlying the cause of pear-shaped tomato fruit., [http://www.pnas.org/cgi/content/abstract/162485999v1] 